\title{
Molecular psychobiology of memory: Its appearance, contributions, and decline
}

\author{
JOHN GAITO \\ York University, 4700 Keele Street, Downsview M3J 1P3, Ontario, Canada
}

\begin{abstract}
The development of molecular psychobiology in its concern with memory aspects is traced over four periods from its inception about 1950 to the present time. There was tremendous excitement during the second period (about 1958-1964) with the expectation that outstanding contributions concerning the molecular basis for memory would be provided. Unfortunately, little was produced of substantial nature; one of the main reasons was the extensive use of methodologies which emphasized quantitative aspects of RNA and protein, rather than methods which might indicate the presence of qualitatively different molecules and their role during learning and memory events. Only three procedures appear to have been suitable in handling these important aspects: DNA-RNA hybridization methods, polyacrylamide gel electrophoresis experiments, and the transfer paradigm. The latter is the only worthwhile one which is in extensive use today.
\end{abstract}

With the rapid development of molecular biology during the 50 s and 60 s, producing important basic contributions, it was inevitable that the ideas and methods of molecular biology would permeate the behavioral sciences as well. Thus it was that during the late 50 s and early 60 s a new area of research and theory gradually developed. This domain has been labeled molecular psychology (Gaito, Note 1), molecular psychobiology (Gaito, 1966, 1971), or molecular neurobiology (Schmitt, 1967). This area of endeavor had as its main concern the uncovering of the molecular mechanisms of memory. Now, however, it appears that molecular psychobiology as a separate and unique entity is rapidly disappearing. The purpose of this paper is to trace the development and decline of this area and to evaluate its contributions. The overall conclusion is that although the approach was a tremendously exciting one, with the expectation that important contributions would be forthcoming, and although much data were generated, little of an outstanding nature was accomplished.

\section{BACKGROUND}

Molecular psychobiology, as an area of research and theory, was concerned with the relationship between gene and gene products (the nucleic acids-DNA, RNAand proteins) and behavior (mainly memory aspects). As the name indicates, it involved an integration of the ideas and methods of psychology with those from molecular biology. However, it included subject matter from a number of scientific disciplines, viz, biochemistry, physical chemistry, biophysics, virology, bacteriology, genetics, cytology, psychology, neurology, neurobiology, neurophysiology, neurochemistry, and neurohistology.

Because molecular biology had made rapid progress, it was assumed by many of the early workers in the area that similar contributions would be provided relative to behavior. Although behavior in general was of some concern, the major effort of most investigators was relative to the molecular basis of learning and memory. Thus many individuals assumed that molecular psychobiology would determine the molecular basis of memory within a few years. The optimism and enthusiasm generated during the early days among a number of researchers was tremendous.

Many researchers in molecular psychobiology assumed that there were one or more specific DNA sites that were quiescent (or relatively so) during nonlearning periods. During learning events, these sites would become active in the synthesis of a specific RNA (presumably messenger RNA) (Bonner, 1964, 1966; Briggs \& Kitto, 1962; Gaito, 1964a, b, 1966). This RNA was then to be translated into specific proteins or polypeptides which performed some important function, possibly at the synapse. There were variations of this theme. However, the important assumption was that there were unique RNA and/or protein molecules present during learning which were not present during nonlearning situations. Furthermore, these unique species of RNA and/or proteins were assumed to form the basis for memory events.

In attempting to determine the relationship between learning and the nucleic acids and proteins, there were two types of procedures utilized: the direct and the indirect procedures.

The direct approach used behavior as the independent variable and neurochemical aspects as the dependent variable. For example, Hyden and Egyhazi (1962) trained rats to climb a wire to obtain food and analyzed the RNA base ratios to determine if these ratios differed in trained and untrained animals; Gaito (Note 2) contrasted the amounts, and specific activities, of RNA and protein in avoidance conditioned and control rats.

The direct approach has a molecular biology empha- 
sis. It requires extensive apparatus, such as high- and low-speed centrifuges, homogenizers and tissue grinders, spectrophotometers, liquid scintillation spectrometers, etc. In time, effort, and money, it involves a more expensive set of operations than does the indirect approach.

The indirect approach reverses the independent and dependent variables; neurochemical variations are the independent variables, while the behavioral measure is the dependent variable. For example, one may administer to an animal a specific chemical which affects DNA, RNA, or protein and then note the effect on learning behavior (e.g., Agranoff \& Klinger, 1964; Barondes \& Cohen, 1968; Zelman, Kabat, Jacobson, \& McConnell, 1963).

The indirect approach has a psychological orientation, because the emphasis (or dependent variable) is behavioral. Usually a single experiment can be completed more quickly with this type of approach than with the direct method.

Some individuals concentrated almost exclusively on one procedure, e.g., Hyden (direct) and McConnell (indirect). However, most individuals, although favoring one approach, used a combination of both.

\section{DEVELOPMENT OF MOLECULAR PSYCHOBIOLOGY}

Although the nucleic acids were known for many years prior to the development of molecular biology, and research on RNA was conducted by Hyden as early as 1943 (Hyden, 1958), no attempt to relate the nucleic acids to learning and memory was made until the late 50s. Molecular psychobiology can be considered as consisting of four periods.

\section{Period 1: Prior to Molecular Biology (About 1950)}

Prior to the rapid development of molecular biology during the 50s, following the classical experiments of Avery, MacLeod, and McCarty (1944) and others, the chemical substance responsible for genetic potential was assumed to be protein. Thus, a number of individuals suggested the possible involvement of proteins in memory events. For example, in 1953, in Scientific American, Gerard summarized his ideas of a number of years on this matter. However, Halstead was the first to provide a detailed set of hypotheses or formulations linking protein to complex behavior. His ideas were presented during the 1948 meeting of the American Psychological Association and then in published form (Halstead, 1951; Katz \& Halstead, 1950). He suggested that nuclear proteins were modified during experience and formed the basis for the recording of such events. Although Halstead's ideas incorporated the misconception that protein was the genetic material, it is obvious that he anticipated the formulations of others who, a decade later, spoke of changes in DNA and/or RNA as the basis for memory (Dingman \& Sporn, 1961; Gaito, 1961; Hyden, 1958). Thus, Halstead should be given credit as a pioneer in molecular psychobiology. At a symposium held during the 1963 meeting of the Midwestern Psychological Association, and at a conference held a year later at Kansas State University, Ward Halstead was referred to as the "Father of Molecular Psychobiology."

\section{Period 2: Early Development in Research and Theory (About 1958 to 1964)}

Halstead had set the stage for the development of molecular psychobiology, but it was not until about a decade later that further developments in research and theory occurred. During this period, with the rapid development of molecular biology and its outstanding contributions, research had firmly established that DNA was the chemical substance of the gene. Thus, theorists and researchers interested in learning and memory began to concern themselves with DNA and its sister molecule, RNA. Furthermore, even though Halstead can be considered the originator of molecular psychobiology, he did not directly influence any of the Period 2 researchers and/or theorists. Rather, the influence came from molecular biology.

One of the first contributions was from an applied area. In Montreal, D. E. Cameron had been concerned for a number of years with attempts to alleviate the ailments of the aged by chemical means. Thus, it was not unusual that eventually he would use the nucleic acids in this effort. Beginning in 1956, he administered yeast RNA and DNA to elderly patients in an attempt to improve their memory and their overall functioning (Cameron, 1958). These yeast RNA experiments seem logically to lead to later "transfer experiments" by McConnell and others.

Other researchers were concerned with basic and theoretical aspects of memory. About 1958, E. Roy John and colleagues conducted research using ribonuclease (RNase), the enzyme that degrades RNA; the effects of intraventricular injections into trained cats were investigated (1958, unpublished work, cited by John, 1967). Later research used RNase with regenerating planarians (Corning \& John, 1961).

Another early researcher was Hyden. Although Hyden had begun analyzing the chemical aspects of RNA in biological experiments during the 40s (Hyden, 1958), he did not relate RNA to learning and memory until the late 50s. His theory of RNA modification in learning was promulgated in 1958 (Hyden, 1958); his first research effort analyzing the quantities of RNA and RNA base ratios in trained and untrained animals was described in 1962 (Hyden \& Egyhazi, 1962).

The "transfer experiments" began during this period. McConnell and his group injected RNA from trained and untrained planarians into naive recipients and reported successful transfer results (Zelman et al., 1963). These experiments were a continuation of the regeneration and cannibalism experiments with planarians (McConnell, 1962; McConnell, Jacobson, \& Kimble, 1959).

Other early research was by Chamberlain, Rothschild, 
and Gerard (1963) and Dingman and Sporn (1961)with 8-azaguanine-and Agranoff and Klinger (1964), Barondes and Jarvik (1964), and Flexner, Flexner, and Stellar (1963)-with RNA or protein synthesis inhibitors-to determine the effects of chemicals on behavior.

The contribution of Gaito at this time was mainly of a theoretical nature. He was influenced by two articles by Crick $(1954,1957)$ in Scientific American, and hypothesized that modification of DNA in the brain might provide the mechanism whereby heredity and environment would interact in behavior (Gaito, 1961). This was one of the first papers with a detailed set of hypotheses in this area of research and theory. Some preliminary research was conducted using RNA/DNA ratios to differentiate brain areas during a learning task (Gaito, 1964b).

During this early period, theories of RNA modification were presented by Cameron (1963), Dingman and Sporn (1961), Hyden (1958), and McConnell (Note 3). DNA modification was suggested by Gaito (1961). These individuals at first had instructive models (change of structure of existing molecules) as opposed to selective models (release of existing molecules or release of potential molecules). The latter were first suggested by Briggs and Kitto (1962) and Smith (1962).

During this period some theoretical ideas were published in journals-the ones indicated above as well as Dingman and Sporn (1964), Gaito (1963), and Gaito and Zavala (1964). Other ideas were either not published or appeared in informal print, such as McConnell's Worm Runner's Digest, in a number of dittoed and mimeographed articles and notes circulated to a small group of interested individuals, and in symposia (e.g., the Midwestern Psychological Association meetings in 1962, 1963; at Kansas State University, 1964).

\section{Period 3: Vigorous Research Efforts (1965 to 1970)}

Soon the field expanded rapidly. The "transfer researchers," influenced by McConnell's planaria work (and possibly indirectly by the yeast RNA experiments of Cameron), became numerous; e.g., Ungar and Oceguerra-Navarro (1965) and Jacobson's group at UCLA (Babich, Jacobson, Bubash, \& Jacobson, 1965). Probably many individuals entering molecular psychobiology at this time were attracted to this work. Most laboratories attempted some research of this nature, as did the Molecular Psychobiology Laboratory at York University, using labeled RNA to determine where in the recipient brain the injected RNA and RNA constituents were located (Schaeffer \& Gaito, Note 4).

Other researchers were Glassman, concerned with the amount of labeled precursors of RNA entering brain tissue during shock avoidance conditioning (e.g., Zemp, Wilson, Schlesinger, Boggan, \& Glassman, 1966), Shashoua (1968) and a host of other individuals. During this period many researchers, too numerous to mention, engaged in an attempt to uncover the relationship between genes and gene products and learning and memory events.

An interesting aspect is the fact that during the first two periods many psychologists were involved (e.g., Corning, Gaito, Halstead, John, and McConnell), whereas during the third period biochemists and geneticists tended to dominate the scene.

\section{Period 4: Decline (1971 to Present)}

It is during this last period that the decline of the area as a formal and unique entity seems most apparent. Although some of the early contributors, such as John and Corning, had left the area early for other interestsJohn (1967) for neurophysiological pursuits and Corning for comparative psychology research-and others (Cameron and Halstead) had died, much research continued during the 70s. However, within the last few years, other researchers have left the area. McConnell has moved to other challenging areas (behavior -modification). The work by Gaito on brain stimulation (Gaito \& Gaito, 1974) may be considered a part of molecular psychobiology, but it seems more appropriate as a part of neuropsychology. The research of the Flexner group began to emphasize characteristics of adrenergic synapses as the important contributors to learning events (Serota, Roberts, \& Flexner, 1972) rather than unique messenger RNAs as at first (Flexner, 1967).

A few of the early researchers have continued their research; however, methodologically it is more or less a repetition of previous procedures. For example, Hyden (1973) reported that increases in calcium accompany change of handedness in rats and hypothesized that these changes effect modification in the conformation of specific proteins. Agranoff and Barondes continue to find impairment in behavior following administration of RNA or protein synthesis inhibitors (Neale, Klinger, \& Agranoff, 1973; Squire \& Barondes, 1974). However, in sharp contrast to the productivity of the late 60 s, fewer papers are now forthcoming from these laboratories.

A number of other individuals are reporting findings of a molecular psychobiological nature (e.g., book edited by Zippel, 1973). However, many efforts are basically repetitions of previous research by others, with some minor variations, and are concerned mainly with changes in quantities (i.e., amounts) of RNA and protein during behavior. Unfortunately, such efforts are of minor importance, inasmuch as the question of quantitative changes has been answered in the affirmative in convincing fashion by many individuals (see, e.g., Gaito, 1966, 1971; Pevzner, 1966).

The only viable research effort of substantial magnitude still being conducted in molecular psychobiology is that using the transfer paradigm.

\section{RESEARCH STRATEGY}

\section{Important Questions and Procedures}

There are three questions of importance in this area. These can be set forth according to relative importance 
and in terms of a logical progression of research effort:

(1) Are there quantitative changes in DNA, RNA, and/or protein which occur during learning and memory events?

This question would seem to be the logical first step in a research effort and the least important question to answer. One would be interested in determining if there were quantitative changes associated with the behavior of concern.

Although some of the changes in amounts of DNA reported during learning events (e.g., Gaito, Koffer, \& Mottin, Note 5) probably indicate a change in absolute amounts of DNA (by glial cell changes, for example), most of the reported changes are relative ones. With an increase or decrease in amounts of RNA and protein, or other cellular constituents, the amounts of DNA per gram of tissue will change also.

There have been many reports indicating RNA and protein quantitative changes during learning and memory (e.g., Hyden \& Egyhazi, 1962; Gaito, Note 3).

(2) Are there qualitative changes in DNA, RNA, and/or protein (i.e., unique RNA or protein molecules) which accompany learning events?

Having determined that quantitative changes occur, research then could be instituted to detect specific types of changes of a unique nature.

Gaito's (1961) early theory in Psychological Review suggested the possibility that qualitative changes resulted in DNA (with adenine changing to guanine, or vice versa, and guanine to cytosine, or vice versa) during experiental events. Thus his early research at Kansas State University evaluated DNA base amounts of dogs and rats subjected to varying degrees of experiences (Gaito, 1966). The results were negative. Unfortunately, even if qualitative changes had occurred in DNA, base analysis procedures are too gross to detect possible differences.

Hyden, in his early work with RNA base ratios, assumed that he was showing qualitative changes in RNA (Hyden \& Egyhazi, 1962). Unfortunately, base ratio changes could indicate quantitative changes in RNA, because this procedure is incapable of differentiating between qualitative and quantitative changes.

There have been two sets of experiments which appeared capable of answering this question, viz, DNARNA hybridization procedures (for RNA) and polyacrylamide gel electrophoresis experiments (for protein).

\section{DNA-RNA hybridization experiments}

A means of attempting to determine if different RNA occurs in learning events is the use of DNA-RNA hybridization procedures. The idea of using hybridization procedures was developed by Gaito from correspondence with James Bonner in 1963, and in discussion with Abraham Eisenstark and Richard Consigli at Kansas State University. This possibility was discussed later in print by Bonner $(1964,1966)$ and by Gaito $(1964 b, 1966)$. If one heats a solution of rat brain DNA at $95^{\circ} \mathrm{C}$ for $10 \mathrm{~min}$, the double-stranded DNA will split into single strands. If this DNA is then poured onto nitrocellulose membranes, these membranes will "trap" single strands but will allow any double strands to pass through. If a membrane with attached DNA is placed in a solution of RNA, those RNA molecules which are complementary in base sequence to DNA sites will become firmly attached and be resistant to RNase treatment. If this DNA-RNA hybrid is put in another solution of the same RNA, no further hybridization will occur because all DNA sites complementary to the RNA already are occupied. On the other hand, if this hybrid is added to a different solution of RNA which is complementary to other DNA sites, further hybridization will occur.

Putting this procedure within a behavioral framework, the rationale is the following. If there exist unique (different) species of brain RNA which are synthesized during learning, and RNA from the brain of a nonlearning animal is added to this hybrid, the unique RNA species should adhere to the DNA. An important aspect of this successive competition hybridization procedure is that only the RNA from learning animals is labeled by radioactive precursors of RNA. Therefore, the presence of label in the twice hybridized DNA will suggest that RNA species not present in the brain of nonlearning animals have been synthesized in learning animals during the task.

These research efforts, beginning in 1965, were summarized by Gaito (1972). The results of the earliest experiments suggested the presence, in shock avoidance conditioned rats, of RNA qualitatively different from that in control animals. However, results in later experiments, using improved procedures, tended to question this possibility. These experiments had to be abandoned before conclusive results, positive or negative, were obtained, because of their tremendous expense in terms of time, effort, and money. Unfortunately, the problem of detecting unique RNA species much less than a microgram in amount is a difficult one.

\section{Polyacrylamide gel electrophoresis experiments}

Polyacrylamide gel electrophoresis does with protein what is accomplished for RNA by hybridization procedures. Different proteins migrate at different rates in the gel in response to an electrical current. Hyden reported results suggesting that a unique protein band was present for trained rats but not for untrained rats (Hyden \& Lange, 1972). (Rats were trained to use the nonpreferred paw to reach for food; other rats, controls, used the preferred paw.)

(3) Do these changes (quantitative and/or qualitative) lead directly to memory development?

This is the most important question for molecular psychobiology and concerns the exact role of the nucleic acids and proteins in behavioral events. It had been assumed that there was a cause-effect relationship with a unique RNA producing a unique protein during learning events. This latter molecule, in some way, represented the basis for the experience in the nervous system. If this assumption is correct, one would expect that the unique RNA and/or protein, when taken from 
one organism and administered to another, would influence the behavior of the latter. Thus the transfer paradigm, which seems to be the only procedure which is relevent to Question 3, involves injecting brain material from trained animals into one group of naive recipients and material from untrained animals into a second group of naive recipients, and then noting the behavior of both groups on the learning task.

The person responsible for the development of this procedure was James McConnell. In a systematic and logical procedure, the transfer experiment was developed with planarians via three steps: natural transfer during regeneration, transfer by cannibalism, and transfer by injection (McConnell, 1962; McConnell et al., 1959; Zelman et al., 1963). Thus, by 1963, McConnell had provided all the necessary results and information for the transfer paradigm to be available for use with planarians or other organisms. It is, therefore, not surprising that, in 1965, a number of different researchers reported the first results using a transfer experiment with rats and mice.

\section{Summary}

If one were successful in answering Question 1 or Question 2 in an affirmative manner, one would then be interested in determining the exact relationship between the chemical changes and the behavior. Although an affirmative answer to Question 1 might lead to an attempt to go directly to Question 3, it seems more logical to answer Question 2 before attacking Question 3.

These three research steps are those which characterized the research effort of Gaito $(1966,1971)$. If DNARNA hybridization procedures had been successful, unique RNA could have been trapped on the membrane, eluted, and administered to naive recipients. Likewise, unique proteins could have been trapped on polyacrylamide gel using the procedures of Hyden and then administered to naive recipients. Unfortunately, Hyden did not incorporate this procedure in his research program.

These research steps and questions are in a logical progression. However, it is possible also to begin with Question 3, as McConnell, Ungar, and many others did with the transfer experiments. ${ }^{1}$ Unfortunately, most researchers did not go to Question 2 when the answer to Question 3 seemed to be affirmative. It is to Ungar's credit that he did use direct procedures in an attempt to answer Question 2 and, thereby, provided added support for his positive transfer results.

\section{EVALUATION OF RESEARCH RESULTS}

The direct approach is efficient in providing information concerning quantitative changes in chemicals which accompany changes in behavior, or in attempting to answer Question 2. However, the direct procedure, by itself, cannot indicate the exact role of these chemicals in the behavior of concern (Question 3).
Likewise, the indirect approach may indicate the effects of specific chemicals on behavior. However, it is no more effective, by itself, than the direct procedure relative to the evaluation of the three questions, without adding some indirect inferences (Barraco \& Stettner, 1976).

Much research (see Gaito, 1966, 1971; Pevzner, 1966) indicated that quantitative changes in gene products (RNA and protein) occur during various behaviors. Generally, if stimulation is mild or moderate (in many behaviors including learning), increases will result; if the stimulation is excessive, decrements are found. However, such quantitative changes are not unusual because, during behavior, one would expect quantitative changes to occur in many chemicals as a result of basic cell events. For example, one would find changes not only in protein and RNA, but likely also in adenosinetriphosphate, oxygen usage, thyroxine, acetylcholine, acetylcholinesterase activity, glucose uptake in cells, etc.

Although finding changes in amounts of specific chemicals accompanying changes in behavior is a necessary first step, such results are of little value in the evaluation of Questions 2 and 3. Therefore, procedures which come to grips with these questions were required. However, many individuals who found changes in amounts of RNA and/or protein concurrently with behavioral changes did not move to other procedures suitable for evaluating the questions of unique species and the exact role of molecules, but instead persisted in the conduct of experiments which were little different from their previous ones. Thus, while more and more information became available with subsequent experiments, this information was of little value relative to Questions 2 and 3.

Unfortunately, there are researchers today who are still conducting experiments of this nature, concerned with quantitative changes. Although important in the early periods, e.g., from around 1960 to about 1966 or so, this effort today is of little value. It is obvious that, during behavior, changes will be found in many chemicals if sensitive procedures are utilized. But this information is trivial unless the researcher is able to go farther and show that the molecular changes involve molecules unique (different) in the behavioral event and that these molecules bring about the behavioral event.

Most of the procedures used in molecular psychobiology have not been suitable for anything but information about quantitative changes; that is the main reason for meager contributions and the decline of this area of investigation. ${ }^{2}$ However, the DNA-RNA hybridization experiments and the polyacrylamide gel experiments (relative to Question 2) and the transfer paradigm (relative to Question 3) appeared to be promising approaches.

At first the results of DNA-RNA hybridization procedures seemed to indicate that the answer to Question 2 (relative to RNA) was affirmative. However, 
as more efficient procedures were incorporated, the positive answers were not as prominent (Gaito, 1972). Nevertheless, there was still a suggestion that unique RNA might be present. The research had to be terminated before conclusive results (positive or negative) could be obtained because of practical and technical problems.

The experiments of Hyden, using polyacrylamide gel electrophoresis, suggested a unique protein, possibly S-100 protein (Hyden \& Lange, 1972). However, these results were not replicated elsewhere, nor were they carried to a logical further step, viz, by incorporating the transfer paradigm.

Of all the approaches, that by Ungar has been the most complete. His transfer experiments suggested that unique molecules were involved in inducing a specific type of behavior in a passive avoidance task. Then he and his colleagues used a variety of direct methods (mainly mass spectroscopy and thin-layer chromatography) to determine the specific chemical involved and its structure.

In evaluating the transfer results of Ungar and others, it is necessary to consider them according to two main aspects.

(a) Is transfer an authentic phenomenon?

At first, transfer seemed to be a real effect, with a number of researchers obtaining positive results (e.g., Babich et al., 1965; Ungar \& Oceguerra-Navarro, 1965). Then, when Byrne et al. (1966) reported negative results from many laboratories, and Luttges, Johnson, Buck, Holland, and McGaugh (1966) also obtained negative results, a wave of negativism set in. However, a second period of positive results followed in which even some individuals who had previously been unsuccessful were now able to obtain positive results (Byrne \& Samuel, 1966). An important step was that by Ungar indicating clearly the conditions required for successful transfer to take place (Ungar, 1972).

Further important events were those of isolating the molecule responsible for the transfer effect in one task, identifying its structure, and then synthesizing it. Ungar, Desiderio, and Parr (1972) isolated from dark-avoidanceconditioned animals a polypeptide called scotophobin, containing 15 amino acids, which was reported to induce dark-avoidance behavior when injected into naive recipients. In synthetic state, this chemical was claimed to produce the same effect. A number of other researchers also obtained significant results (e.g., Bryant, Santos, \& Byrne, 1972; Guttman, Mattwyshyn, \& Warriner, 1972; Malin \& Guttman, 1972; McConnell, personal communication). Other research, however, did not show this effect (e.g., Ali, Faesal, Sarantakis, Stevenson, \& Weinstein, 1971; Goldstein, Sheehan, \& Goldstein, 1971), and a detailed article by Stewart (1972) raised questions about the overall methodology and conclusions of the scotophobin advocates.

There have been so many successful transfer results that one must conclude that the phenomenon is an authentic one, even though some individuals still question its authenticity (Ungar, 1972; Dyal, Note 6). Furthermore, we expect that many chemicals will produce a behavioral effect when administered to a recipient. Why should we not expect a behavioral effect when chemicals are removed from one animal and injected into another one? Thus, at this time, the phenomenon seems to be genuine, although not always reproducible.

(b) Is the transfer effect a memory or a nonmemory one?

This is the question which is difficult to determine conclusively. Ungar and many others maintain that memory aspects are involved and cite successful attempts to induce the required behavior in a specific fashion (Ungar, 1974). Critics offer a number of objections. One is that with the intraperitoneal (IP) injections used, little or none of the injected substance will pass the blood-brain barrier (e.g., Luttges et al., 1966). This "barrier" acts by various mechanisms to restrict the entry of some materials into the brain and to facilitate the entry of others; these mechanisms include osmosis, ultrafiltration, and chemical factors such as net charge, lipid solubility, affinity of transport carrier systems, and specific aspects of tissue metabolism (Mcllwain \& Bachelard, 1971). Rate of entry can be effected either rapidly or very slowly. Although much research has indicated that molecules such as RNA and protein do not pass the blood-brain barrier (Luttges et al., 1966; also see Gaito, 1971), Ungar found that a proportion of IP-injected scotophobin is in brain areas within $15 \mathrm{~min}$ after injection (Ungar, 1973).

A second objection concerns the passive avoidance task used by Ungar. Goldstein (1973) pointed out that learning is complete in one or several trials; however, with Ungar using 6 days of five trials each, or 30 trials overall, great emotionality was produced. Thus, Goldstein concluded that, if positive transfer occurs, an emotional factor could be the transfer agent. Ungar's response to this objection is that 30 trials are required to obtain maximum quantities of scotophobin; he reported results (1973) which indicated maximum amounts after 6 days of five trials each. Furthermore, Ungar (1973) and others (Bryant et al., 1972; Dyal, Note 6) reported that at least some of the positive transfer results are of specific nature, not of a general nature as would be predicted if an emotional component were responsible for the transfer effect.

One disturbing feature is that the Ungar (1973) report indicated that injected material reached the brain within $15 \mathrm{~min}$ and was at a maximum in $2 \frac{1 / 4}{\mathrm{~h}}$, but that no traces were detectable after $24 \mathrm{~h}$. Yet Ungar (1972) specified that "the schedule of testing, particularly the interval between administration of the extract and the first trial, is an extremely critical factor. In almost all the successful experiments, the effect was not detectable in less than $24 \mathrm{~h}$ and often only 48 to $72 \mathrm{~h}$ afterwards. 
In most of the negative experiments, testing was done early-between 4 and $24 \mathrm{~h}$ and usually only once" (p. 89). Thus, the injected material is detected in the brain when successful transfer is not supposed to occur, but is not detected when transfer is expected. However, Ungar handles this aspect by assuming that the polypeptide needs to be incorporated into some cellular structures, viz, synaptic membranes, to have an effect, and in this state is not detectable (Ungar, 1974).

At this moment, it is difficult to conclude that the scotophobin of Ungar and other polypeptides that are being isolated and identified (Ungar, 1974) are unique "memory factors." Unfortunately, many individuals reject the transfer results, and specifically the scotophobin results, without a fair and objective explanation. Whether scotophobin is a "memory factor" or not is an empirical question which should be resolved within a few years. The results may indicate eventually that Ungar's approach has been successful in providing "memory factors." However, one should take the null hypothesis position and assume that empirical investigations will show that "behavior inducers" of a nonmemory nature are involved. In any event, no matter what the final outcome, the transfer work by McConnell and its extension by Ungar represented the most imaginative, and potentially the most useful, set of procedures within molecular psychobiology.

In closing this section, the author would like to express a personal opinion concerning the most important contributors to this area. There were three contributors of major importance, viz, Cameron, McConnell, and Ungar.

D. E. Cameron deserves credit as the first person, or at least one of the first, to initiate research relating RNA and/or DNA directly to memory aspects. This research, in which he administered yeast RNA or DNA to elderly patients in an attempt to improve their memory and well-being, was a pioneer effort. Furthermore, this research can be considered as a predecessor to the transfer paradigm. If McConnell's planarian work had not been conducted, Cameron's research could have been seen as leading directly to the transfer experiment.

James McConnell deserves credit for his ingenuity in devising the transfer experiments and for his courage in maintaining them in spite of much adverse criticism. He probably influenced more people in this area, in either a positive or negative fashion, than did any other individual.

Finally, Georges Ungar deserves credit for taking the transfer paradigm and proceeding to show (at least to the satisfaction of himself and many others) that the transfer effect is a real one under certain well-defined conditions. He then systematically proceeded to use direct methods to uncover unique molecules which were assumed to be responsible for the transfer effect. If the research efforts within the next few years indicate that Ungar has uncovered one or more "memory factors," his contributions will be of the greatest magnitude. However, even if these molecules bring about "behavioral facilitation" or some other nonmemory effect, his contributions still will be of substantial value.

\section{CONCLUDING COMMENTS}

At this point in time, in the late 70 s, it seems appropriate to conclude that most of molecular psychobiology is rapidly dying, with the only viable research programs making use of the transfer paradigm in some way. The contributions by so many researchers have been of modest value. There was a period of about a decade and a half of great excitement and expectations. Unfortunately, the full expectations engendered during the early days of optimism and excitement have not been fulfilled, or may not be fulfilled. Today these aspects are just a pleasant nostalgic memory!

\section{REFERENCE NOTES}

1. Gaito, J. A biochemical conceptualization of learning and memory. Symposium: Models in Psychology. R. Forgus (Chmn.) Midwestern Psychological Association Meetings, Chicago, Illinois, May 1962.

2. Gaito, J. Molecular psychobiology laboratory: Development and progress. Technical Report MPL 11, York University, Toronto, Ontario, 1967.

3. McConnell, J. V. A tape recorder theory of RNA. Symposium: Nucleic Acids and Behavior, J. Gaito (Chmn.) Midwestern Psychological Association Meetings, Chicago, Illinois, May 1963.

4. Schaeffer, E., \& Gaito, J. The effect of RNA injections on shock avoidance conditioning and on brain chemistry. Technical Report, MPL 7, York University, Toronto, Ontario, 1966.

5. Gaito, J., Koffer, K., \& Mottin, J. The effects of auditory stimulation and motor activity on nucleic acids and proteins. Technical Report MPL 1, York University, Toronto, Ontario, 1965.

6. Dyal, J. A. Transfer of behavioral bias: Reality and specificity. Technical Report No. 1, Dept. of Psychology, University of Waterloo, 1970.

7. Gaito, J. Nucleic acids and learning. Mimeographed paper, Kansas State University, August 1963.

\section{REFERENCES}

Agranoff, B. W., \& Klinger, P. D. Puromycin effect on memory fixation in the goldfish. Science, 1964, 146, 952-953.

Ali, A., Faesal, J. H. R., Sarantakis, D., Stevenson, D., \& Weinstein, B. Synthesis of a structure proposed for scotophobin. Experientia, 1971, 27, 1138.

Avery, O. T., MacLeod, C. M., \& McCarty, M. Studies on the chemical nature of the substance inducing transformation of pneumonococeal types. Induction of transformation by a deoxyribonucleic acid fraction isolated from Pneumococeus Type III. Journal of Experimental Medicine, 1944, 79, 137-147.

Babich, F. R., Jacobson, A. L., Bubash, S., \& Jacobson, A. Transfer of a response to naive rats by injection of ribonucleic acid extracted from trained rats. Science, 1965, 149, 655-657.

Barondes, S. H., \& Cohen, H. D. Arousal and conversion of "short term" to "long term" memory. Proceedings of the National Academy of Sciences, 1968, 61, 923-929.

Barondes, S. H., \& JARVIK, M. E. The influences of actinomycinD on brain RNA synthesis and on memory. Journal of Neurochemistry, 1964, 11, 187-195.

Barraco, R. A., \& Stettner, L. J. Antibiotics and memory. Psychological Bulletin, 1976, 83, 242-302. 
BonNER, J. The molecular biology of memory - summary. In J. Gaito (Ed.), Symposium on the role of macromolecules in complex behavior. Manhattan, Kans: Kansas State University, 1964.

BonNer, J. Molecular biological approaches to the study of memory. In J. Gaito (Ed.), Macromolecules and behavior. New York: Appleton-Century-Crofts, 1966.

Briggs, M. H., \& Kitto, G. B. The molecular basis of memory and learning. Psychological Review, 1962, 69, 537-541.

Bryant, R. C., Santos, N. N., \& Byrne, W. L. Synthetic scotophobin in goldfish: Specificity and effect on learning. Science, 1972, 177, 635-636.

Byrne, W. L., \& SAMUEL, D. Behavioral modification by injection of brain extract prepared from trained donors. Science, 1966, $154,418$.

BYRNE, W. L., \& 22 others. Memory transfer. Science, 1966, 153, 658.

Cameron, D. E. The use of nucleic acid in aged patients with memory impairment. American Journal of Psychiatry, 1958, 114, 943.

Cameron, D. E. The process of remembering. British Journal of Psychiatry, 1963, 109, 325-333.

Chamberlain, T. J., Rothschild, G. H., \& Gerard, R. Drugs affecting RNA and learning. Proceedings of the National Academy of Sciences, 1963, 49, 918-924.

Corning, W. C., \& JoHN, E. R. Effect of ribonuclease on retention of conditioned response in regenerated planarians. Science, 1961, 134, 1363-1365.

CRICK, F. H. C. The structure of the hereditary material. Scientific American, 1954, 191, 54-61.

CRICK, F. H. C. The nucleic acids. Scientific American, 1957, 197, 188-200.

Dingman, W., \& SpoRn, M. B. The incorporation of 8-azaguanine into rat brain RNA and its effect on maze-learning by the rat: An inquiry into the biochemical bases of memory. Journal of Psychiatric Research, 1961, 1, 1-11.

Dingman, W., \& SPORN, M. B. Molecular theories of memory. Science, 1964, 144, 26-29.

Flexner, J. B., Flexner, L. B., \& Stellar, E. Memory in mice as affected by intracerebral puromycin. Science, 1963, 141, 57-59.

FlexNer, L. B. Dissection of memory in mice with antibiotics. Proceedings of the American Philosophical Society, 1967, 111, 343-346.

GaIto, J. A biochemical approach to learning and memory. Psychological Review, 1961, 68, 288-292.

GAITo, J. DNA and RNA as memory molecules. Psychological Review, 1963, 70, 471-480.

GAITo, J. DNA derepression and behavior. Psychological Reports, 1964, 15, 276. (a)

GaITo, J. Nucleic acids and brain function. In J. Gaito (Ed.), Symposium on the role of macromolecules in complex behavior. Manhattan, Kans: Kansas State University, 1964. (b).

GaITo, J. Molecular psychobiology: A chemical approach to learning and other behavior. Springfield, Ill: Thomas, 1966.

GaITo, J. DNA complex and adaptive behavior. Englewood Cliffs, N.J: Prentice-Hall, 1971.

GAITo, J. Successive competition DNA-RNA hybridization procedures to detect the presence or absence of qualitative changes in RNA during behavioral events. International Journal of Psychobiology, 1972, 2, 163-176.

GAITo, J., \& GAITo, S. T. Interanimal transfer of the kindling effect. Physiological Psychology, 1974, 2, 379-382.

Gaito, J., \& Zavala, A. Neurochemistry and learning. Psychological Bulletin, 1964, 61, 45-62.

GERARD, R. W. What is memory? Scientific American, 1953, 189, 118-126.

Goldstein, A. Comments on the "Isolation, identification and synthesis of a specific-behaviour-inducing brain peptide."
Nature, 1973, 242, 60-62.

Goldstein, A., Sheehan, P., \& Goldstein, J. Unsuccessful attempts to transfer morphine tolerance and passive avoidance by brain extracts. Nature, 1971, 233, 126-129.

Guttman, H. N., Matwyshyn, G., \& Warriner, G. H., III. Synthetic scotophobin mediated passive transfer of dark avoidance. Nature, 1972, 235, 26-27.

Halstead, W. C. Brain and intelligence. In L. A. Jeffress (Ed.), Cerebral mechanism in behavior. New York: Wiley, 1951.

Hyden, H. Biochemical changes in glial cells and nerve cells at varying activity. In E. Brucke (Ed.), Proceedings of the 4th International Congress of Biochemistry. Biochemistry of the central nervous system (Vol. III). London: Pergamon Press, 1958.

HydEN, H. Neuronal plasticity, protein conformation and behavior. In H. P. Zippel (Ed.), Memory and transfer of information. New York: Plenum, 1973.

Hyden, H., \& EgYhazi, E. Nuclear RNA changes of nerve cells during a learning experiment in rats. Proceedings of the National Academy of Sciences, 1962, 48, 1366-1373.

Hyden, H., \& LANGe, P. W. Correlation of the S-100 brain protein with behavior. In J. Gaito (Ed.), Macromolecules and behavior (2nd ed.). New York: Appleton-Century-Crofts, 1972.

John, E. R. Mechanisms of memory. New York: Academic Press, 1967.

Katz, J. J., \& Halstead, W. C. Protein organization and mental function. Comparative Psychology Monographs, 1950, 20 (No. 103), 1-38.

Luttges, M., Johnson, T., Buck, C., Holland, J., \& McGaugh, J. An examination of "transfer of learning" by nucleic acid. Science, 1966, 151, 834-837.

Malin, D. H., \& Guttman, H. H. Synthetic rat scotophobin induces dark avoidance in mice. Science, 1972, 178, 1219-1220.

McConnell, J. V. Memory transfer through cannibalism in planarians. Journal of Neuropsychiatry, 1962, 3, 42-48.

McConnell, J. V., Jacobson, A. L., \& Kimble, D. P. The effect of regeneration upon retention of a conditioned response in the planarian. Journal of Comparative and Physiological Psychology, 1959, 52, 1-5.

McIlWAIN, H., \& BACHELARD, H. S. Biochemistry and the central nervous system. London: Churchill Livingstone, 1971.

Neale, J. H., Klinger, P. D., \& Agranoff, B. W. Camptothecin blocks memory of conditioned avoidance in the gold fish. Science, 1973, 179, 1243-1246.

Pevzner, L. Z. Nucleic acid changes during behavioral events. In J. Gaito (Ed.), Macromolecules and behavior. New York: Appleton-Century-Crofts, 1966.

Schmit, F. O. Molecular neurobiology in the context of the neurosciences. In G. C. Quarton, T. Melnechuk, \& F. O. Schmitt (Eds.), The neurosciences. New York: Rockefeller University Press, 1967.

Serota, R. G., Roberts, R. B., \& Flexner, L. B. Acetoxycycloheximide-induced transient amnesia: Protective effects of adrenergic stimulants. Proceedings of the National Academy of Sciences, 1972, 69, 340-342.

Shashoua, V. E. RNA changes in goldfish during learning. Nature, 1968, 217, 238-240.

SMITH, C. E. Is memory a matter of enzyme induction? Science, 1962, 138, 889-890.

SQuire, L. R., \& Barondes, S. H. Anisomycin, like other inhibitors of cerebral protein synthesis, impairs "long term" memory of a discrimination task. Brain Research, 1974, 66, 301-308.

STEWART, W. W. Comments on the chemistry of scotophobin. Nature, 1972, 238, 202-209.

UNGAR, G. Biological assays for the molecular coding of acquired information. In J. Gaito (Ed.), Macromolecules and behavior (2nd ed.). New York: Appleton-Century-Crofts, 1972.

UNGAR, G. The problem of molecular coding of neural information: A critical review. Naturvissenshaften, 1973, 60, 307-312. 
Ungar, G. Peptides and memory. Biochemical Pharmacology, 1974. 23, 1553-1558.

Ungar, G., Desiderio, D. M., \& ParR, W. Isolation, identification and synthesis of a specific-behavior-inducing brain peptide. Nature, 1972, 238, 198-202.

UNGAR, G., \& OCEguERRA-NAVARRo, C. Transfer of habituation by material extracted from brain. Nature, 1965, 207, 301-302.

Zelman, A., Kabat, L., Jacobson, R., \& McConnell, J. V. Transfer of training through injection of "conditioned" RNA into untrained planarians. Worm Runner's Digest, 1963, 5, 14-21.

Zemp, J. W., Wilson, J. E., Schlesinger, K., Boggan, W. O., \& Glassman, E. Brain function and macromolecules. I. Incorporation of uridine into RNA of mouse brain during short-term training experiences. Proceedings of the National Academy of Sciences, 1966, 55, 1423-1431.

ZipPEL, H. P. (Ed.). Memory and transfer of information. New York: Plenum, 1973.

\section{NOTES}

1. In early work at Kansas State University, Gaito (Note 8) considered using the transfer paradigm as well as numerous other methodological possibilities with rats. He rejected the transfer paradigm because he assumed that the "noise level" contributed by "nonunique RNA" would be too great and would obscure the effects of "unique RNA," if unique RNA did exist. He assumed that a more efficient procedure would be to locate brain areas in the rat which differentiate a learning rat from a control animal and then to evaluate specific neurochemical events within those areas (Gaito, 1964b, 1966).

2. A number of other reasons for the decline of molecular psychobiology might be suggested. These include:

(a) Lack of cooperation of psychologists, chemists, physiologists, etc., in team efforts to handle the required interdisciplinary research.

(b) Lack of financial support for research of individuals in areas of controversy (e.g., transfer experiments) but adequate support for those performing noncontroversial, and in some cases rather trivial, research. This lack of support occurred when the validity and importance of the research began to be questioned, although a number of plausible hypotheses were still to be tested. Support further decreased in recent years as funds from U. S. granting agencies diminished drastically for all research efforts.

(c) Lack of a theory which could integrate the molecular, synaptic, physiological, and behavior events.

(d) Differential meanings of the word "learning" among different researchers; likewise, differential meanings of the word "memory" at the molecular, physiological, and behavioral levels.

Each of these aspects probably contributed to some degree.

(Received for publication June 4, 1976; revision accepted August 13, 1976.) 